\title{
Strontium stable isotope behaviour accompanying dehydration of antigorite-bearing serpentinite
}

\author{
LEWIS W ROBINSON ${ }^{1}$, KEVIN W BURTON ${ }^{2}$, GEOFF M \\ NOWELL ${ }^{1}$, HELEN M WILLIAMS ${ }^{3}$, VICENTE LOPEZ \\ SANCHEZ-VIZCAINO ${ }^{4}$ AND CARLOS J. GARRIDO $^{5}$ \\ ${ }^{1}$ Durham University \\ ${ }^{2}$ University of Durham \\ ${ }^{3}$ University of Cambridge \\ ${ }^{4}$ Universidad de Jaen \\ ${ }^{5}$ Instituto Andaluz de Ciencias de la Tierra (IACT/CSIC) \\ Presenting Author: lewis.w.robinson@durham.ac.uk
}

Serpentinites are ubiquitous in subduction zones, comprising a portion of the subducting slab and/or the shallow mantle wedge. These rocks are believed to be a key reservoir for fluid-mobile elements, halogens and other trace elements in this context. Although serpentinites are widely studied, details concerning the delivery of serpentinite dehydration fluids from the subducting slab to the overlying crust and mantle remain poorly understood. Serpentinite derived fluid ligand geochemistry is of specific interest as this, in part, influences the partitioning of many elements during dehydration. Strontium stable isotopes are useful in determining the nature of such fluids as light $\mathrm{Sr}$ isotopes are preferentially incorporated into carbonate or sulfate in the presence of $\mathrm{CO}_{3}{ }^{2-}$ and $\mathrm{SO}_{4}{ }^{2-}$ rich fluids.

This study presents high-precision ${ }^{87} \mathrm{Sr} /{ }^{86} \mathrm{Sr}$ and $\delta^{88 / 86} \mathrm{Sr}$ for ultra-mafic rocks from across the antigorite-out dehydration front at Cerro del Almirez ultramafic massif (Nevado-Filabride Complex, Betics, S. Spain) [e.g. 1]. Antigorite-bearing serpentinites possess relatively radiogenic ${ }^{87} \mathrm{Sr} /{ }^{86} \mathrm{Sr}(0.708703)$ and typical mantle $\delta^{88 / 86} \mathrm{Sr}$ values $(0.32 \pm 0.02 \%$ ). Dehydration is accompanied by a general increase in $\mathrm{Sr}$ concentration; granofels-textured chlorite-harzburgites, orthopyroxene-olivine (opx-ol) serpentinites, and some spinifex-textured harzburgites show a shift towards relatively unradiogenic ${ }^{87} \mathrm{Sr} /{ }^{86} \mathrm{Sr}$ (down to 0.7075032 ) and lighter $\delta^{88 / 86} \mathrm{Sr}$ (as light as $0.099 \pm 0.025$ ). The shifts in ${ }^{87} \mathrm{Sr} /{ }^{86} \mathrm{Sr}$ rule out substantial involvement of metasediment sourced fluids during open-system serpentinite dehydration, as these sediments possess highly radiogenic $\mathrm{Sr}$ isotope compositions. Rather, the high $\mathrm{Sr}$ concentrations and relatively unradiogenic ${ }^{87} \mathrm{Sr} /{ }^{86} \mathrm{Sr}$ compositions point to an additional Sr-rich source with a low $\mathrm{Rb} / \mathrm{Sr}$ ratio, such as metarodingites [2] or meta-ophicalcites [3] boudins found within the ultramafic complex. The light $\delta^{88 / 86} \mathrm{Sr}$ composition is also consistent with the formation of anhydrous minerals, such as orthopyroxene, from a carbonate (or sulfate) rich fluid, accompanying the processes leading to the formation of spinifex and granofels textures in the harzburgite $[4,5]$.

[1] Debret et al. (2021) Geochim. Cosmochim. Acta 296, 210225. [2] Laborda-López et al. (2020) Lithos 370, p.105639. [3] Menzel et al. (2019) J. Metam.Geol.37, 681-715. [4] PadrónNavarta et al. (2011) J Pet. 52 2047-2078. [5] Dilissen et al. (2021) Lithos 382, p.105949. 